\title{
Studies on Infant Diarrhea. I. A Comparison of the Effects of Milk Feeding and Intravenous Therapy upon the Composition and Volume of the Stool and Urine*
}

\author{
R. Torres-Pinedo, $†$ M. Lavastida, $\ddagger$ C. L. Rivera, $\$$ H. Rodrïguez, and \\ A. ORTIZ \\ (From the General Clinical Research Center, the Department of Pediatrics of the School of \\ Medicine, and the University Hospital, University of Puerto Rico, San Juan, \\ Puerto Rico)
}

The generally accepted concept that metabolic acidosis in infant diarrhea results from the loss of buffer base in the stool has been based on the common observation that inorganic cations predominate over inorganic anions in diarrheal stools $(1-5)$. This predominant loss of inorganic cations has been taken as evidence of loss of bicarbonate. On the other hand, Teree, Mirabal-Font, Ortiz, and Wallace (6) have shown by direct measurements that the $\mathrm{pH}$ of the stool water in infant diarrhea is frequently acidic (almost always below the $\mathrm{pH}$ of the blood) and that $\mathrm{HCO}_{3}-$ is very low or absent. On the basis of the observed differences between $\mathrm{Na}^{+}+\mathrm{K}^{+}$and $\mathrm{Cl}^{-}$, these authors have suggested that there is a high concentration of organic anions in diarrheal stools of infants and have advanced several hypotheses to explain the origin of these substances (7).

The effect of fecal loss of organic anion on acidbase balance will depend upon several factors. These include the origin of the organic anions (i.e., whether ingested preformed, or generated within the body) and the nature of the cations accompanying them (8). Those organic acids generated in the intestinal lumen or elsewhere in the body change the $\mathrm{H}^{+}$concentration of the body fluids, depending upon the degree of ionization of

* Submitted for publication April 29, 1965 ; accepted December 16, 1965.

Supported by grant FR-63-03 from the Division of Research Facilities and Resources, U. S. Public Health Service, and AM 07595-02 from the National Institute of Arthritis and Metabolic Diseases.

† Address requests for reprints to Dr. R. Torres-Pinedo, General Clinical Research Center, School of Medicine, University of Puerto Rico, San Juan, P.R.

$\ddagger$ Research fellow supported by grants AM 07595-02 and 1-S01-FR-05119-02, National Institutes of Health. the acids (6) and the nature of the cations (organic or inorganic) neutralizing the dissociated acids in the stool. Loss of organic anions formed within the body in excess of organic cations isolates $\mathrm{H}^{+}$in the body fluids.

Thus it would appear that knowledge of the organic acid content of the stool and of the possible sources of these acids might shed some light on the pathogenesis of metabolic acidosis in diarrheal disease. Furthermore, if protons are released in the body because of loss of organic anions in the stool, the net effect on blood acid-base equilibrium will depend on the efficiency of the renal acidification mechanism and possibly on the action of other extrarenal mechanisms $(9,10)$. Although renal excretion of acid has been studied during recovery from diarrheal dehydration $(11,12)$, no similar data during development of acidosis are available.

In the present study, we have attempted to reproduce in a group of infants with acute diarrhea the conditions under which systemic acidosis usually ensues in that disease. By this means changes in stool composition could be studied, and the influence of milk intake on the composition of the stools and on the acid-base equilibrium could be assessed and compared with similar observations during fasting and intravenous therapy. In addition, specific challenges with individual sugars were provided to some patients, and the changes induced in stool composition were studied.

\section{Methods}

Relevant clinical information about the 13 infants who were the subjects of this study is summarized in Table I. The majority of the infants studied were referred to us from a Health Center located in an area of Puerto Rico where infectious diarrhea is widespread. The requisite 
TABLE I

Clinical data on infants with acute diarrhea

\begin{tabular}{|c|c|c|c|c|c|c|c|}
\hline Patient & Age & Sex & $\begin{array}{c}\text { Body } \\
\text { weight }\end{array}$ & $\begin{array}{c}\text { Duration of } \\
\text { diarrhea }\end{array}$ & $\begin{array}{l}\text { Intake during } \\
\text { prior } 24 \text { hours }\end{array}$ & Stool culture & Clinical course \\
\hline & & & $\mathrm{kg}$ & days & & & \\
\hline 1. $\mathrm{CLO}$ & 17 days & $\mathbf{M}$ & 2.64 & 2 & Evaporated milk & Coliform bacteria & Recovered \\
\hline 2. IGM & 2 months & $\mathbf{F}$ & 4.48 & 1 & Evaporated milk & Coliform, Proteus & Recovered \\
\hline 3. SVZ & 4 months & $\mathbf{M}$ & 4.39 & 2 & Evaporated milk & Coliform, Proteus & Died \\
\hline 4. MA & 14 days & $\mathrm{F}$ & 3.00 & $\frac{1}{2}$ & Evaporated milk & Escherichia coli 055:B5 & Recovered \\
\hline 5. LRB & $1 \frac{1}{2}$ months & $\mathrm{M}$ & 4.05 & $\stackrel{2}{1}$ & Evaporated milk & Escherichia coli 055 :B5 & Recovered \\
\hline 6. $\mathrm{ZH}$ & 2 months & $\mathrm{F}$ & 3.15 & 2 & Cow's milk & Klebsiella aerogenes & Recovered \\
\hline 7. CRM & 4 months & $\mathbf{F}$ & 5.43 & $\overline{5}$ & iv fluids & Proteus & Recovered \\
\hline 8. MFV & 6 months & $\mathrm{F}$ & 7.33 & 6 & iv fluids & Coliform bacteria & Recovered \\
\hline 9. APB & $1 \frac{1}{2}$ months & $\mathrm{M}$ & 3.30 & $40^{*}$ & iv fluids & Klebsiella aerogenes & Recovered \\
\hline 10. RV & 2 months & $\mathbf{M}$ & 3.66 & 3 & Evaporated milk & Coliform bacteria & Recovered \\
\hline 11. EZS & $1 \frac{1}{2}$ months & $\mathbf{M}$ & 4.44 & 4 & Evaporated milk & & Recovered \\
\hline 12. JMR & 21 days & $\mathbf{M}$ & 2.77 & 16 & Evaporated milk & Escherichia coli 055 :B5 & $\begin{array}{l}\text { Lactose } \\
\text { intolerance }\end{array}$ \\
\hline 13. $\mathrm{MJT}$ & 4 months & $\mathbf{M}$ & 5.20 & 2 & Evaporated milk & Proteus, Klebsiella & Recovered \\
\hline
\end{tabular}

* Off and on.

for admission to the study was the presence of loose stools at the time of observation. Since our purpose was to study the effect of milk feeding on the development of systemic acidosis, infants who showed obvious clinical signs of acidosis were not chosen. Patients 1 to 6 presented very loose and abundant stools on admission. These infants had been kept on milk formulas or cow's milk and received no intravenous therapy or antibiotics for the treatment of diarrhea. Patients 7 to 9 had received intravenous therapy for 24 hours or longer at the time of admission. Infants 10,11 , and 13 suffered moderate diarrhea of short duration and had been maintained on evaporated milk formulas. Patient JMR (No. 12) had developed diarrhea at the age of 5 days, which subsided during a period of 3 days of intravenous therapy. Diarrhea recurred soon after restarting milk feeding. This patient still does not tolerate milk at the age of 3 months and develops diarrhea upon administration of lactose. He does well with a milk substitute that contains sucrose as the only source of carbohydrate. All the other patients except SVZ (No. 3) recovered and were free of diarrhea on subsequent examinations. Infant SVZ died of diarrhea and malnutrition 1 month after the studies.

Whenever possible, the patients (No. 1 to 9) were studied during three consecutive 12-hour periods: a) administration, either by bottle or gavage, of about $100 \mathrm{ml}$ per $\mathrm{kg}$ of body weight of a dilute evaporated milk formula (15 calories per ounce); $b$ ) intravenous infusion of an approximately $0.05 \mathrm{M}$ sodium chloride solution containing $5 \%$ glucose; $c$ ) intravenous infusion of an approximately $0.05 \mathrm{M}$ sodium bicarbonate solution. Potassium chloride was added to each solution so as to infuse $1.5 \mathrm{mEq}$ of potassium per $\mathrm{kg}$ of body weight per 12-hour period.

In Patients 10 to 13 the sugar was administered on alternate days. During the intervals between sugar loading, these infants were maintained on a mixture of calcium caseinate, corn oil, electrolyte, and water, to pro- vide amounts of protein, fat, and electrolytes approximately equal to those ordinarily obtained from milk. The calculated requirements for carbohydrate were given intravenously as $10 \%$ glucose in water. Diarrhea improved quickly with this regimen, and the sugar was given when the infants were having scanty, although at times liquid, stools. A period of fasting of 6 hours, without glucose administration, preceded each test.

The infants were placed in a metabolic crib where urine and feces were collected separately and under oil. An indwelling catheter was used for urine collection during the first period. It was subsequently removed and an external collection device used instead. Intramuscular colistin was administered for 36 hours to all infants. For easy removal of the stool bags after each bowel movement, the plastic bags were held in place by circular steel frames that were attached under the crib and could be swung back and forth in position. Urine was measured by volume and stool by weight. In liquid stools, sampling for lactic and organic acids was made immediately after excretion, before centrifugation. Centrifugation of the stools at 2,000 rpm for 5 minutes yielded abundant supernatant liquid used for the remaining analyses. In liquid stools, the analytical procedures for acid-base parameters were always performed within 30 minutes after excretion. In semiliquid stools, the liquid phase was obtained by ultrafiltration in a refrigerated centrifuge at $2^{\circ} \mathrm{C}$ for 2 hours (13).

The $\mathrm{pH}$ of serum, urine, stool water, and milk was measured with a Beckman expanded scale potentiometer (model 76) and $\mathrm{CO}_{2}$ content with the Natelson gasometer (14). All pH values were corrected to $37^{\circ} \mathrm{C}$. In urine, stool water, and milk, ammonia was determined by a micromodification of the Conway titration method (15), titratable acidity by electrometric titration in a dual recording automatic titrator, and organic acids by the method of Greenwald (16) and by electrometric microtitration. Blood pyruvate and lactate were determined by the enzymatic method (17) (change in absorption at 


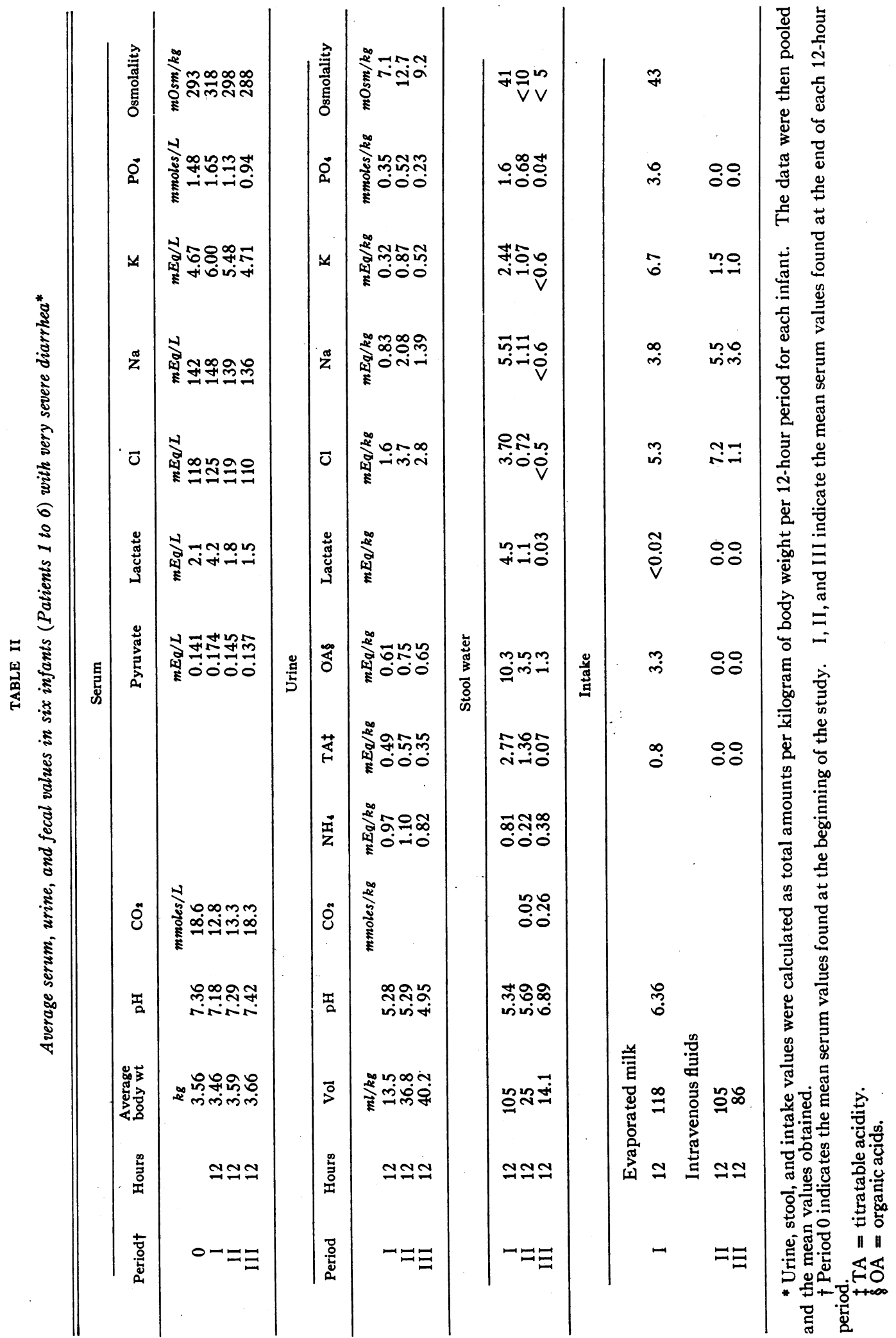




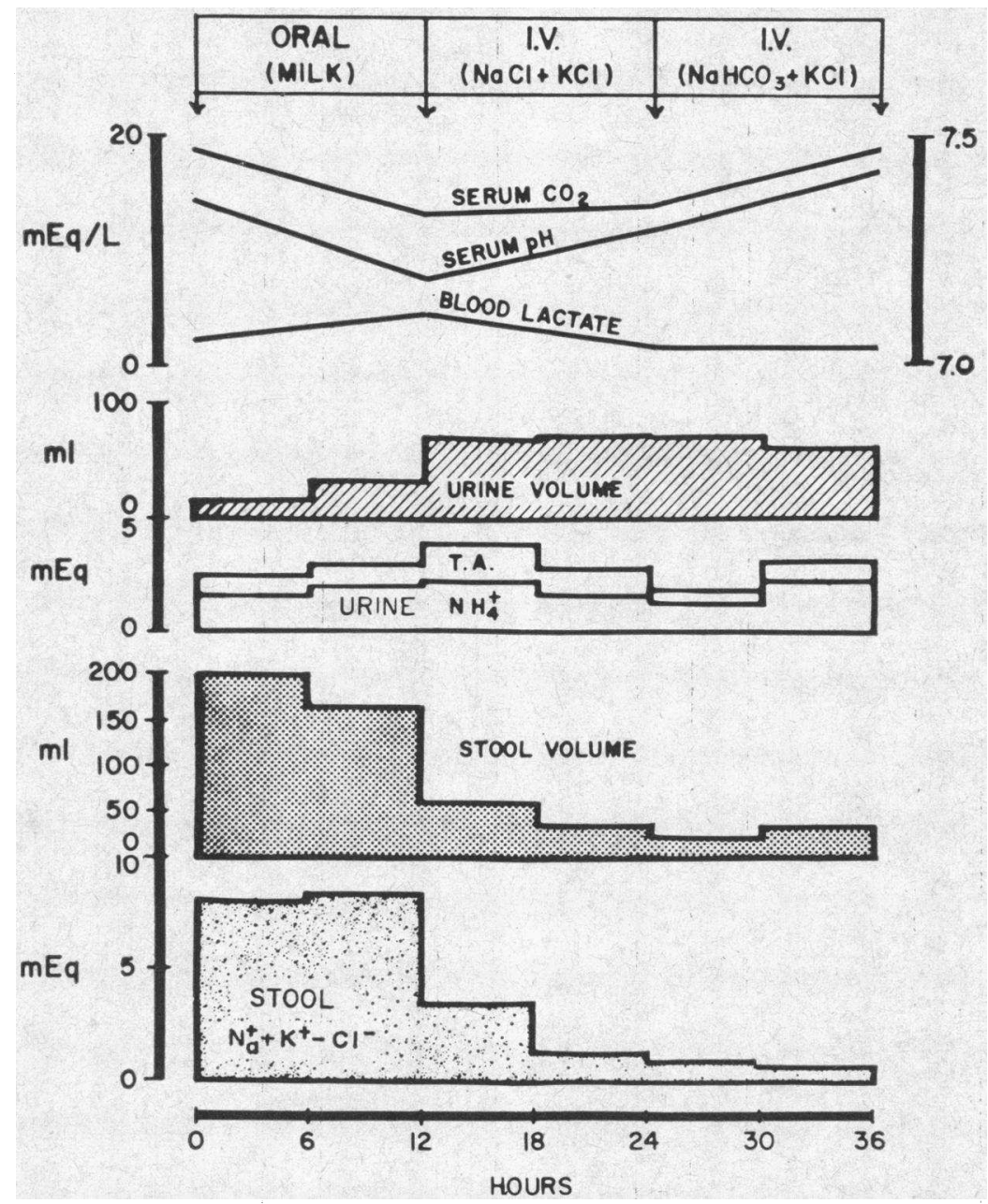

Fig. 1. Development of, ANd Partial ReCovery From, Systemic acidosis in Patients 1 to 6 . Urine and stool values represent the average of the totals per 6-hour period. $\mathrm{TA}=$ titratable acidity.

$340 \mathrm{~m} \mu$ of appropriate nucleotides). The same method was used for stool and milk lactate determinations. In blood, urine, stool water, milk, and electrolyte solutions, the concentrations of sodium and potassium were determined by flame photometry in a Technicon autoanalyzer, those of chloride with a Cotlove chloridometer (18). Inorganic phosphate was determined by the method of Fiske and Subbarow (19). Osmolalities were measured by the freezing point depression technique. Blood sugar was determined by Nelson's modification of the Somogyi method (20). Total carbohydrate in the feces was determined by the anthrone reaction (21). The individual sugars were subsequently identified by paper chromatography (22). Fructose in the feces was measured by the method of Roe, Epstein, and Goldstein (23).

\section{Results}

Table II presents the average data from six infants aged 14 days to 4 months who exhibited very severe diarrhea. A representative example of this group is given in Table III. All of these infants had stool volumes above $300 \mathrm{ml}$ in the first 12 hours. The relatively small average change in body weight was due to the concomitant high intake of milk. Metabolic acidosis and simultaneous rise of blood lactate occurred in all patients (Figure 1). Urine volume decreased markedly, and despite normal or high urine concentrations of $\mathrm{NH}_{4}{ }^{+}$and titratable acidity (TA) the net excretion of $\mathrm{H}^{+}\left(\mathrm{NH}_{4}{ }^{+}+\mathrm{TA}\right)$ was low (mean, $1.46 \mathrm{mEq}$ per $\mathrm{kg}$ body weight; $\mathrm{SD} \pm 0.5$ ). The effect of milk feeding was apparent in both volume and acidity of the stools (Table II). The low stool $\mathrm{pH}$ (mean, $5.34 ; \mathrm{SD} \pm 0.27$ ) was due to the high concentration of organic acids of which lactic acid accounted for roughly one-half the total. The mean total fe- 
cal excretion of organic acids was $10.3 \mathrm{mEq}$ per $\mathrm{kg}$ of body weight during this period. A representative example of the organic acid titration curves obtained is given in Figure 2. It was evident that at the actual $\mathrm{pH}$ of the stools almost all other organic acids of $\mathrm{pKa}$ above that of lactate were in ionized form as well. Phosphate excretion in the stool was high as compared to the subsequent periods. Stool titratable acidity (mean, $25.5 \mathrm{mEq}$ per $\mathrm{L} ; \mathrm{SD} \pm 8.0$ ) varied as expected with the $\mathrm{pH}$ and the concentrations of inorganic phosphate and undissociated organic acids. Figure 3 illustrates the average anion-cation composition and the measured osmolalities of stool water. Sulfate, $\mathrm{Ca}^{++}$, and $\mathrm{Mg}^{++}$were not measured. A considerable discrepancy between measured ions and osmolalities was noted during the feeding periods. For the purpose of our calculations it was assumed that all the unidentified organic anions were monovalent. This is not likely but serves to indicate the maximal possible contribution of the latter sulsstances to the total osmolarity. The unaccounted for osmotically active substances were roughly estimated at about $90 \mathrm{mOsm}$ per L during the feeding period. This fraction decreased

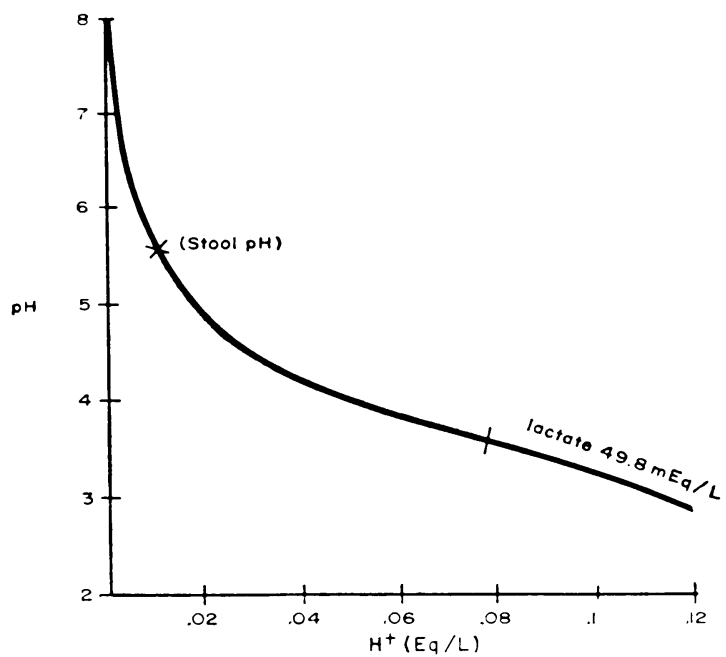

Fig. 2. Organic acid titration curve of stool water IN THE LAST SAMI'LE COLLECTED DURING THE FEEDING PERIOD IN Patient CLO (No. 1). Of the total $120 \mathrm{mEq}$ per $\mathrm{L}$ of organic acids $110 \mathrm{mEq}$ per $\mathrm{L}$ was dissociated at the actual stool $\mathrm{pH}(5.58)$.

subsequently to become negligible during fasting.

During the second 12-hour period (Table II) milk ingestion was discontinued. The effect of this change was reflected in both volume and com-

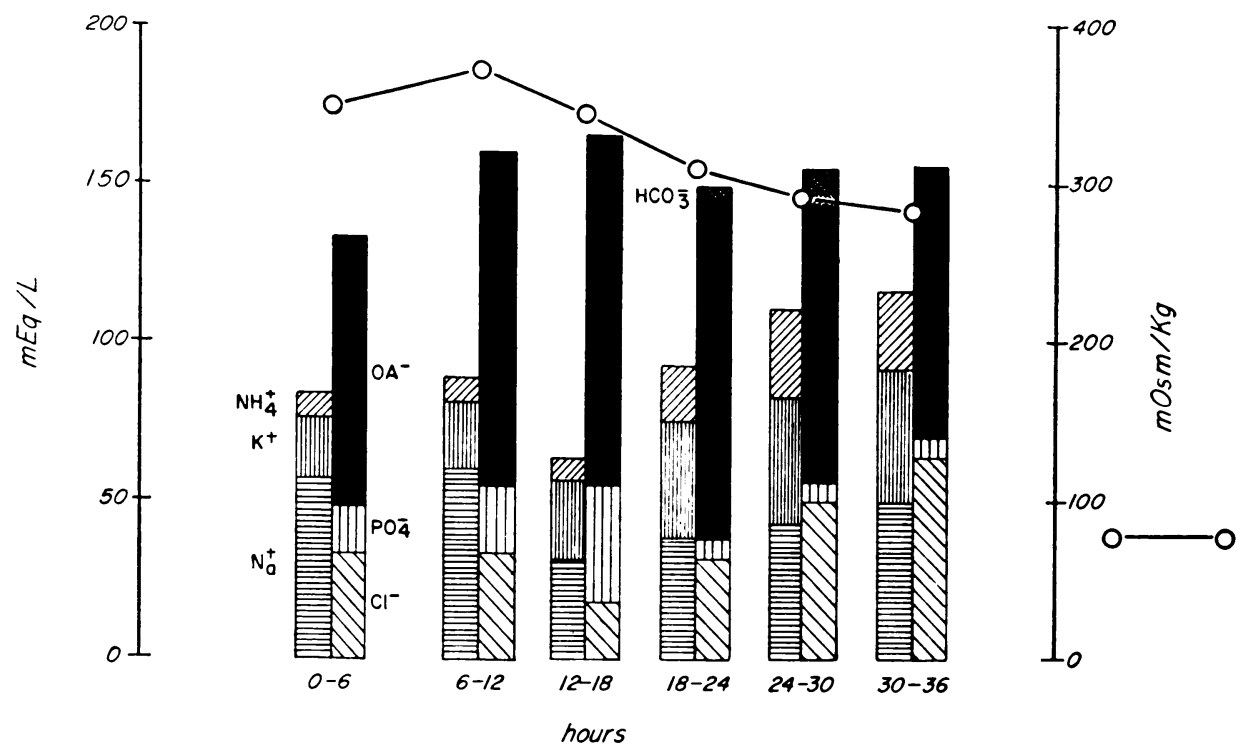

Fig. 3. Average anion-cation composition (Left ordinate) and osmolalities (Right ORDINATE) FOUND IN THE STOOL WATER FroM THE SIX INFANTS SUMMARIzed in TABLE II. Phosphate is represented as millimoles per liter. The valence of phosphate actually increased with alkalinization of the stools during the fasting state. Bicarbonate appeared in the stools after 6 hours of fasting (hours 18 to 24) and increased rapidly toward the end of the study. Although the osmotic activity of organic anions and unmeasured cations could not be accurately assessed, the measured osmolalities during the feeding periods were higher than would have been predicted from the electrical neutrality diagrams. $\mathrm{OA}=$ organic acids. 


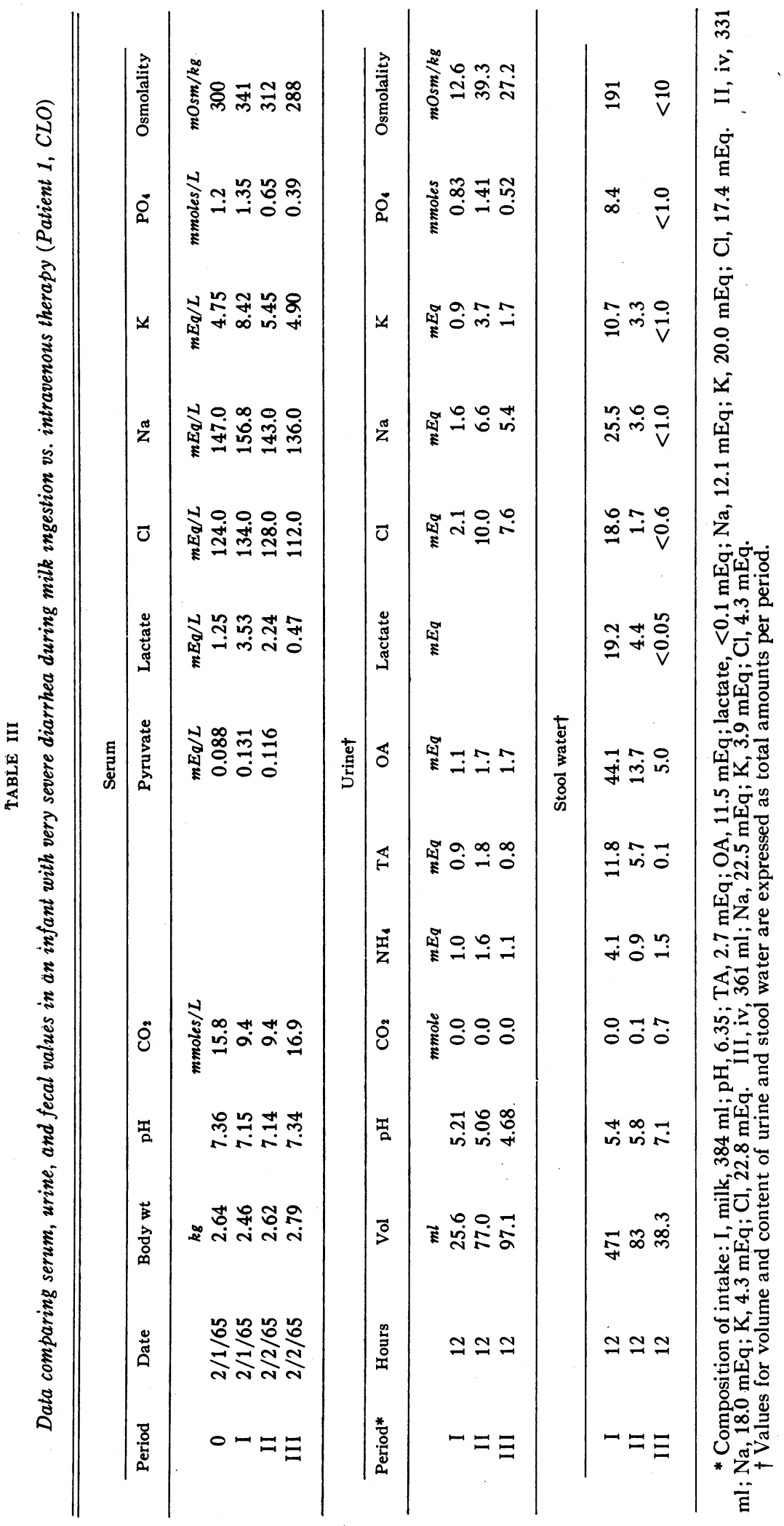



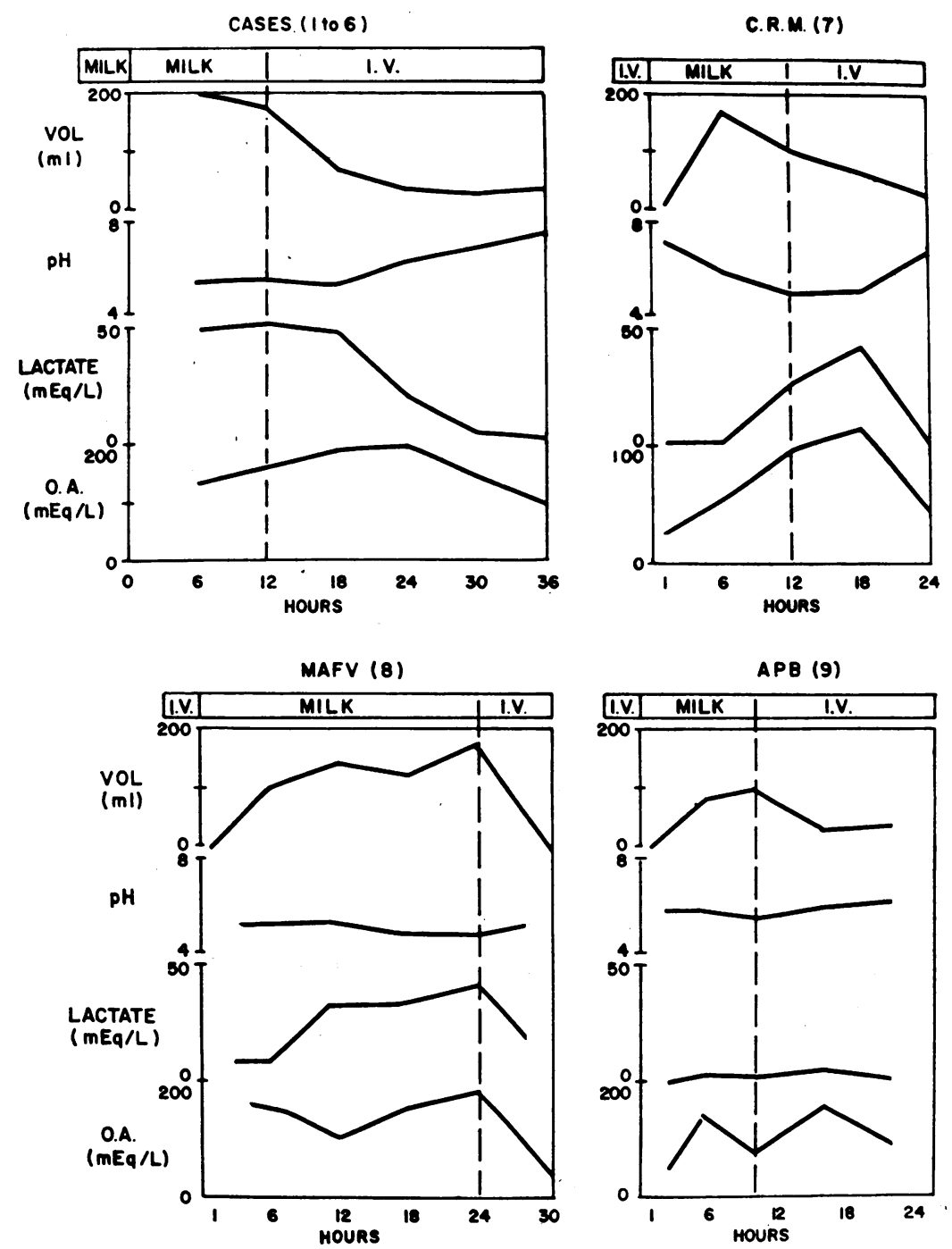

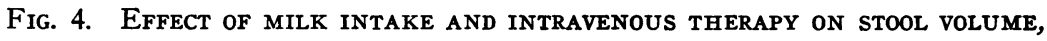
ACIDITY, AND CONCENTRATION OF LACTATE AND ORGANIC ACIDS.

position of urine and feces. The observed change in serum $\mathrm{pH}$ was mainly due to respiratory compensation. A decrease of blood lactate was also observed. Urinary excretion of $\mathrm{H}^{+}$increased slightly (mean, $1.67 \mathrm{mEq}$ per $\mathrm{kg}$ of body weight; $\mathrm{SD} \pm 0.5)$. Stool $\mathrm{pH}$ rose gradually to reach a mean of 5.69, and excretion of bicarbonate was noticed toward the end of this period. The simultaneous stepwise decrease in lactate concentration is seen in Figure 4. These changes were accentuated in the last study period. At this time stool $\mathrm{pH}$ rose to a mean of 6.89 ( $\mathrm{SD} \pm 0.6$ ), bicarbonate was excreted in increasing amounts, and the lactate content of the stool became very low (mean,
$0.03 \mathrm{mEq}$ per $\mathrm{kg}$ body weight). Mean fecal excretion of organic acids was $1.3 \mathrm{mEq}$ per $\mathrm{kg}$ of body weight in the last 12 -hour period. This almost tenfold reduction in organic acid output was accounted for mainly by the virtual disappearance of lactic acid from the feces and the marked decrease in stool volume. Comparison of the values obtained for each one of the various parameters measured in the stools during the first and last 12-hour periods revealed that the observed changes were all statistically significant $(p<0.01)$.

Attempts to obtain an inverse sequence of compositional changes in the feces were made in three infants (Patients 7 to 9) who had not had oral in- 
take for 24 hours or longer. The changes in stool volume, $\mathrm{pH}$, organic acids, and lactate concentrations that occurred upon milk administration are shown in Figure 4. In one of these infants (CRM, Patient 7) the changes were striking. This infant had a marked respiratory alkalosis during the study, so that the findings must be interpreted with caution. Figure 5 gives the organic acid titration curves in stool water at the beginning and end of the feeding period and after intravenous therapy in CRM. There was a considerable increase in the concentration of dissociated organic acids during milk intake and subsequent decrease with fasting and intravenous therapy. In MAFV (No. 8) milk intake caused an increase in stool volume and an increase in lactate concentration in stool water. After institution of intravenous therapy stool volume and stool concentration of lactate and total organic acids decreased. The third patient, APB (No. 9), had very little lactate in his stools throughout the study, and the organic acid content was not affected by the intake of milk.

Effect of oral sugar loads on stool composition. The response to the oral administration of glucose, lactose, and sucrose was studied in four infants (Patients 10 to 13 ). Fructose was also given to

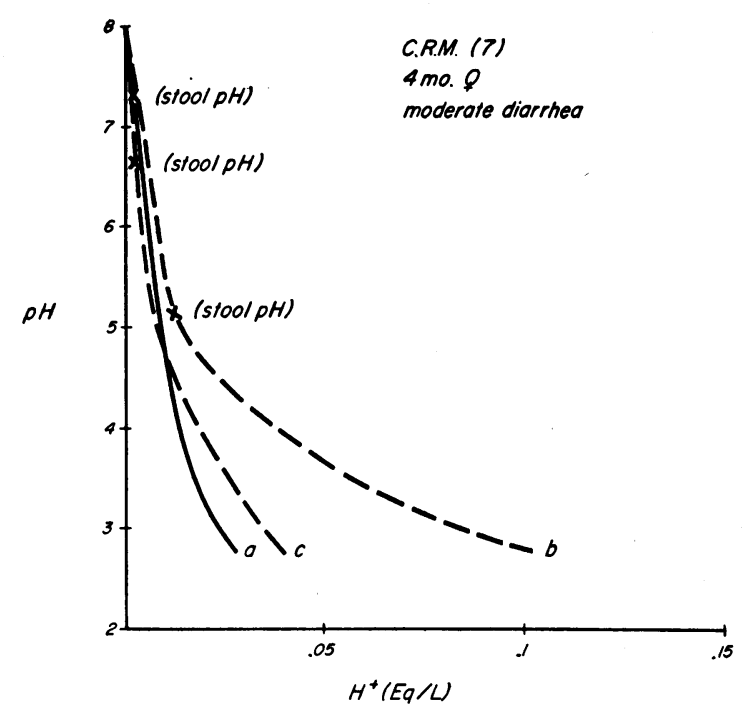

Fig. 5. Evolution OF THE ORGANIC ACID TITRATION CURVE IN THE STOOL WATER OF AN INFANT (CRM, No. 7) ON INTRAVENOUS THERAPY AT THE START OF THE STUDY. a) Beginning of milk intake; $b$ ) end of milk intake; $c$ ) after 10 hours of intravenous therapy.

No. 12. Table IV documents the excretion of large quantities of carbohydrate in the feces in response to the ingestion of various sugars. This occurred not only with the disaccharides, but also with glucose in infants EZS, JMR, and MJT.

TABLE IV

Fecal excretion of carbohydrate after sugar loading in four infants (Patients 10 to 13) with acute diarrhea

\begin{tabular}{|c|c|c|c|c|c|c|c|c|}
\hline \multirow[b]{2}{*}{ Patient } & \multirow[b]{2}{*}{$\begin{array}{l}\text { Duration } \\
\text { of period }\end{array}$} & \multirow[b]{2}{*}{$\begin{array}{l}\text { Sugar ad- } \\
\text { ministered }\end{array}$} & \multirow[b]{2}{*}{ Amount } & \multirow{2}{*}{$\begin{array}{l}\text { Increase in } \\
\text { blood } \\
\text { sugart }\end{array}$} & \multicolumn{4}{|c|}{ Fecal values* } \\
\hline & & & & & Weight & $\Delta \mathrm{pH} \ddagger$ & Total sugar & $\begin{array}{l}\text { Sugars identified by } \\
\text { chromatography }\end{array}$ \\
\hline & hours & & $g$ & $\underset{m l}{m g / 100}$ & $g$ & & $m g$ & \\
\hline 10. $\mathrm{RV}$ & $\begin{array}{l}12 \\
12 \\
12\end{array}$ & $\begin{array}{l}\text { Glucose } \\
\text { Lactose } \\
\text { Sucrose }\end{array}$ & $\begin{array}{l}6 \\
6 \\
6\end{array}$ & $\begin{array}{r}56.0 \\
0.0 \\
56.0\end{array}$ & $\begin{array}{r}30.9 \\
126.8 \\
38.3\end{array}$ & $\begin{array}{l}6.9-7.25 \\
7.21-4.89 \\
6.89-6.91\end{array}$ & $\begin{array}{r}9 \\
1,282 \\
23\end{array}$ & Lactose, glucose, maltose \\
\hline 11. EZS & $\begin{array}{l}12 \\
12 \\
12\end{array}$ & $\begin{array}{l}\text { Glucose } \\
\text { Lactose } \\
\text { Sucrose }\end{array}$ & $\begin{array}{l}8 \\
8 \\
8\end{array}$ & $\begin{array}{l}66.5 \\
31.8 \\
37.4\end{array}$ & $\begin{array}{l}65.7 \\
57.3 \\
41.0\end{array}$ & $\begin{array}{l}7.32-5.84 \\
8.04-4.14 \\
6.40-4.82\end{array}$ & $\begin{array}{r}402 \\
1,389 \\
1,027\end{array}$ & $\begin{array}{l}\text { Glucose } \\
\text { Sucrose, glucose, fructose }\end{array}$ \\
\hline 12. JMR & $\begin{array}{l}12 \\
12 \\
12 \\
12\end{array}$ & $\begin{array}{l}\text { Glucose } \\
\text { Fructose } \\
\text { Lactose } \\
\text { Sucrose }\end{array}$ & $\begin{array}{l}6 \\
6 \\
8 \\
8\end{array}$ & $\begin{array}{l}61.0 \\
84.0 \\
34.0 \\
36.0\end{array}$ & $\begin{array}{r}17.0 \\
188.0 \\
62.9 \\
60.0\end{array}$ & $\begin{array}{ll}7.0 & -6.4 \\
7.3 & -4.12 \\
7.4 & -4.6 \\
7.0 & -5.1\end{array}$ & $\begin{array}{r}424 \\
5,606 \\
473 \\
1,150\end{array}$ & $\begin{array}{l}\text { Glucose } \\
\text { Fructose } \\
\text { Lactose, glucose } \\
\text { Sucrose, fructose }\end{array}$ \\
\hline \multirow[t]{2}{*}{ 13. $\mathrm{MJT}$} & $\begin{array}{l}12 \\
12\end{array}$ & $\begin{array}{l}\text { Glucose } \\
\text { Lactose }\end{array}$ & $\begin{array}{l}10 \\
10\end{array}$ & $\begin{array}{l}60.0 \\
46.2\end{array}$ & $\begin{array}{l}40.0 \\
82.0\end{array}$ & $\begin{array}{ll}7.1 & -6.0 \\
7.4 & -4.6\end{array}$ & $\begin{array}{r}600 \\
2,124\end{array}$ & $\begin{array}{l}\text { Glucose, sucrose } \\
\text { Lactose, glucose, } \\
\text { galactose }\end{array}$ \\
\hline & 12 & Sucrose & 10 & 30.2 & 80.0 & $7.4-5.3$ & 1,160 & Sucrose \\
\hline
\end{tabular}

* Values refer to the total stools collected in a 12-hour period immediately after the sugar loading, but stools were collected upon passage and analyzed separately.

$t$ Maximal increase in blood sugar in 2 hours after sugar loading.

$\ddagger \Delta \mathrm{pH}$ : The first figure represents control values; the second is the maximal change observed in the next 12 hours after sugar loading. 

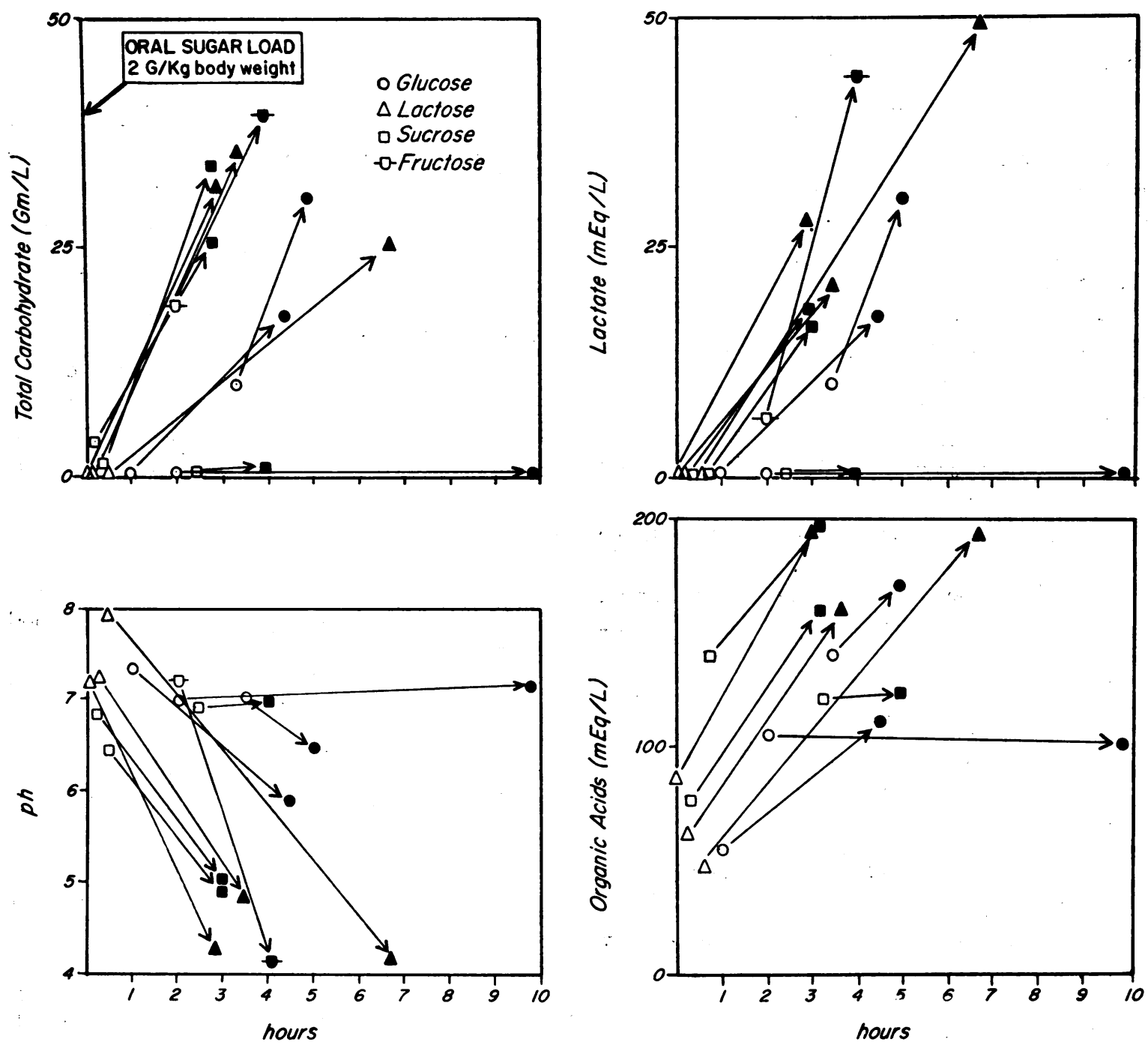

Fig. 6. Changes in the concentrations of total Carbohydrate, lactate and organic acids, AND PH IN STOOL WATER AFTER ORAL SUgar LOAding IN THREe PATIENTS (No. 10,11,12). Arrows indicate the point at which the change was maximal (closed symbols) as compared with the values found in the first stool passed after administration of the sugar (open symbols).

The specific sugars recovered from stools and identified by chromatography were those ingested or their derivatives. Administration of fructose to one infant (JMR) was followed by the excretion in the feces of an almost equivalent amount of this sugar. In the other patients, however, only 5 to $21 \%$ of the ingested sugar was recovered as total sugar in the stool. The increase in blood sugar in response to the administered carbohydrate was variable. As seen in Figure 6, increase in the concentration of fecal sugar was invariably accompanied by a fall in stool $\mathrm{pH}$ and rise in the concentrations of lactic and organic acids. The fecal excretion of carbohydrate increased progressively to reach a peak and subsequently returned to the initial values. Similar curves were obtained for stool acidity and lactic and organic acids. Attempts were made to compare this response of infants with diarrheal disease with that of healthy infants after similar loads, but during fasting the latter passed only very scanty stools, if any, which were not suitable for analysis. Preliminary observations were also made on the carbohydrate content of the feces in newborn infants receiving evaporated milk formulas. The 24-hour carbohydrate excretion was usually under $100 \mathrm{mg}$ and 
never surpassed $200 \mathrm{mg}$. This seems to agree with the findings of Ford and Howarth (24).

\section{Discussion}

The present observations indicate conclusively that the acidity of the feces in infant diarrhea is determined by the presence in the voluminous stool of large amounts of lactic acid and other organic acids of $\mathrm{pKa}$ below that of bicarbonate. Lactate concentration in the stools was initially high in those infants with severe diarrhea who had not been fasting, and was found to increase progressively with milk ingestion in two other infants who had previously been fasting. This pattern was reversed soon after milk intake was stopped and intravenous therapy started. Under these circumstances, the appearance of bicarbonate in the stools suggests that this ion had been initially neutralized by the generation of stronger acids. A definite explanation of the source of these organic acids cannot be offered, but the following hypothesis is suggested. If proximal absorption of carbohydrate were impaired to some degree during the acute stage of infant diarrhea, the resulting large supply of these substances to distal segments of the bowel might cause overproduction of lactic acid and other organic acids, most probably as a consequence of bacterial anaerobic metabolism. Some support for this thesis is lent by observations of others that are mentioned below, as well as by the response to the oral sugar loading in four of our patients.

Increased stool acidity due to production of large quantities of organic acids (lactic, formic, acetic, isobutyric) has been reported in patients with chronic diarrhea due to lack of specific disaccharide-splitting enzymes (25). Blood acid-base parameters in these patients were not reported, so that it is not known whether they had systemic acidosis. It was observed that acidification of the stools was initially determined by increased production of acetic acid. The resultant lowering of the $\mathrm{pH}$ stimulated the proliferation of lactic acidforming bacteria.

Disaccharidase deficiencies are known to occur as a temporary abnormality in infants with prolonged diarrhea (26-28). A recent report has demonstrated the inability of children with protein and calorie malnutrition to absorb lactose, with a rapid decline of the lactic acid of the stools after a carbohydrate-free diet (29). Production of organic acids by intestinal bacteria has been clearly shown to play a role in the development of diarrhea and acidosis in sheep when continuously fed with wheat $(30,31)$.

The changes in stool volume and composition that followed a single oral dose of sugar in four of our patients were qualitatively similar to those observed with milk ingestion. In addition, a large proportion of the sugar administered was recovered in the feces. However, this only proves that the unabsorbed carbohydrate increases stool output and the water content of the feces by some as yet unknown mechanism. Whether the accompanying changes in composition emerge directly from the metabolism of these substances in the intestinal lumen or within the mucosal cells, or indirectly as a consequence of the disturbance produced in intestinal function, remains undetermined. Wrong and associates have recently found by their method of in vivo dialysis of the colonic contents that the concentration of organic anions in the fecal dialysates of normal adult subjects is very high (mean, $179 \mathrm{mEq}$ per L) (32). Our data show that the average concentration of these substances in the liquid phase of diarrheal stools during milk feeding was lower ( $100 \mathrm{mEq}$ per $\mathrm{L}$ ), but the total excretion was relatively high in these infants because of the large stool volumes. The lactic acid content of the stools in infant diarrhea appears to be much greater than in normal stools of adults (32). Nevertheless, the present observations do not exclude the possibility that carbohydrates, through their action on stool volume, exert a sweeping effect on acids secreted and normally reabsorbed at different segments of the bowel.

Milk administration during the development of diarrhea generally had a deleterious effect on acidbase equilibrium. A severe metabolic acidosis developed simultaneously with marked increments in stool output and excretion of organic anion. Analysis of the milk revealed that equivalent amounts of these anions had not been ingested preformed. Thus, it must be assumed that these compounds were largely generated within the body, i.e., in the intestinal tract or endogenously. Inasmuch as the organic acids were excreted in the feces largely as neutralized dissociated salts it seems reasonable to conclude that their production contributed to the metabolic acidosis. 
The renal excretion of $\mathrm{H}^{+}$was entirely inadequate for the observed degree of systemic acidosis and did not change appreciably with fluid replacement and increasing urine volume, suggesting that failure of renal compensation during periods of increasing acid loads to the body plays an important role in the systemic acid-base disturbance of diarrheal disease.

\section{Summary}

The composition of serum, urine, and stool water was studied in nine infants with diarrhea during consecutive periods of milk feeding and intravenous therapy. The effect of oral loads of monosaccharides and disaccharides on stool $\mathrm{pH}$ and content of carbohydrate, lactate, and total organic acids was studied in four additional infants recovering from diarrhea.

During milk administration the stools were very abundant, markedly acidic, and contained large quantities of lactate and other organic acids of low pKa. All these parameters decreased markedly with fasting. The oral administration of sugar loads was followed by increasing fecal excretion of carbohydrate and by compositional changes qualitatively identical to those observed after ingestion of milk.

These observations suggest that the high content of lactate and other organic anions in diarrheal stools of infants is related to carbohydrate ingestion. Increased fecal excretion of endogenously produced organic acid anions in their neutralized, dissociated form probably plays an important role in the genesis of the metabolic acidosis in this condition.

\section{Acknowledgments}

We are grateful to Dr. M. Soto-Viera for referring the patients to us, and to Mr. W. Román, Mrs. M. Jiménez, Mrs. N. del Toro, Miss B. Jiménez, Mrs. N. Figueroa, and Mrs. A. Weisz for their technical assistance.

\section{References}

1. Holt, L. E., A. M. Courtney, and H. L. Fales. The chemical composition of diarrheal as compared with normal stools in infants. Amer. J. Dis. Child. 1915, 9, 213.

2. Finberg, L., C-S. Cheung, and E. Fleishman. The significance of the concentrations of electrolytes in stool water during infantile diarrhea. J. Dis. Child. 1960, 100, 809.

3. Chung, A. W. The effect of oral feeding at different levels on the absorption of foodstuffs in infantile diarrhea. J. Pediat. 1948, 33, 1.

4. Darrow, D. C. The retention of electrolyte during recovery from severe dehydraţion due to diarrhea. J. Pediat. 1946, 28, 515.

5. Kooh, S. W., and J. Metcoff. Physiologic considerations in fluid and electrolyte therapy with particular reference to diarrheal dehydration in children. J. Pediat. 1963, 62, 107.

6. Teree, T. M., E. Mirabal-Font, A. Ortiz, and W. M. Wallace. Stool losses and acidosis in infant diarrhea (abstract). J. Pediat. 1963, 63, 853.

7. Teree, T. M., E. Mirabal-Font, A. Ortiz, and W. M. Wallace. Stool losses and acidosis in diarrheal disease of infancy. Pediatrics 1965, 36, 704.

8. Relman, A. S., E. J. Lennon, and J. Lemann, Jr. Endogenous production of fixed acid and the measurement of the net balance of acid in normal subjects. J. clin. Invest. 1961, 40, 1621.

9. Goodman, A. D., J. Lemann, Jr., E. J. Lennon, and A. S. Relman. Production, excretion, and net balance of fixed acid in patients with renal acidosis. J. clin. Invest. 1965, 44, 495.

10. Lemann, J., Jr., E. J. Lennon, A. D. Goodman, J. R. Litzow, and A. S. Relman. The net balance of acid in subjects given large loads of acid or alkali. J. clin. Invest. 1965, 44, 507.

11. Sampaio Zacchi, M. A. Investigation of the Mechanisms of Metabolic Acidosis in Dehydration Due to Infant Diarrhea. Brazil, Faculty of Medicine of the University of São Paulo, 1964.

12. Gordillo, P. G., L. E. Todd, and G. Paz Martinez. Exploración preliminar de la capacidad tubular de regulación ácido-básica durante la acidosis metabólica causada por diarrea. Mexico, Fourteenth Meeting of the Association of Pediatric Investigation, 1962.

13. Toribara, T. Y., A. R. Terepka, and P. A. Dewey. The ultrafiltrable calcium of human serum. I. Ultrafiltration methods and normal values. J. clin. Invest. 1957, 36, 738.

14. Natelson, S. Microtechniques of Clinical Chemistry, 2nd ed. Springfield, Ill., Charles C Thomas, 1961, p. 152.

15. Conway, E. J. Microdiffusion Analysis and Volumetric Error, 3rd ed. London, Crosby Lockwood, 1950, p. 95.

16. Greenwald, I. Studies on metabolism in pneumonia. I. The excretion of "organic acid" and a method for its determination. J. biol. Chem. 1930, 85, 447.

17. Olson, G. F. Optimal conditions for the enzymatic determination of L-lactic acid. Clin. Chem. 1962, 8, 1.

18. Cotlove, E., M. V. Trantham, and R. L. Bowman. An instrument and method for automatic, rapid, accurate, and sensitive titration of chloride in biological samples. J. Lab. clin. Med. 1958, 51, 461. 
19. Fiske, C. H., and Y. Subbarow. The colorimetric determination of phosphorus. J. biol. Chem. 1925, 66,375 .

20. Nelson, N. A photometric adaptation of the Somogyi method for the determination of glucose. J. biol. Chem. 1944, 153, 375.

21. Scott, T. A., Jr., and E. H. Melvin. Determination of dextran with anthrone. Analyt. Chem. 1953, 25, 1656.

22. Bickel, H., and F. Souchon. Die Papierchromatographie in der Kinderheilkunde. Arch. Kinderheilk. 1955, 31 (suppl.).

23. Roe, J. H., J. H. Epstein, and N. P. Goldstein. A photometric method for the determination of inulin in plasma and urine. J. biol. Chem. 1949, 178, 839.

24. Ford, J. D., and J. L. Haworth. The fecal excretion of sugars in children. J. Pediat. 1963, 63, 988.

25. Weijers, H. A., J. H. van de Kamer, W. K. Dicke, and J. Ijsseling. Diarrhea caused by deficiency of sugar splitting enzymes. I. Acta paediat. (Uppsala) $1961,50,55$.

26. Clarke, J. T., W. Quillian, and H. Shwachman. Chronic diarrhea and failure to thrive due to intestinal disaccharidase insufficiency. Pediatrics 1964, 34, 807 .
27. Launiala, K., J. Perheentupa, J. Visakorpi, and N. Hallman. Disaccharidases of intestinal mucosa in a patient with sucrose intolerance. Pediatrics 1964, 34, 615.

28. Sunshine, P., and N. Kretchmer. Studies of small intestine during development. III. Infantile diarrhea associated with intolerance to disaccharides. Pediatrics 1964, 34, 38.

29. Bowie, M. D., G. L. Brinkman, and J. D. L. Hansen. Acquired disaccharide intolerance in malnutrition. J. Pediat. 1965, 66, 1083.

30. Bullen, J. J., and R. Scarisbrick. Enterotoxæmia of sheep: experimental reproduction of the disease. J. Path. Bact. 1957, 73, 495.

31. Bullen, J. J., and I. Batty. Experimental enterotoxæmia of sheep: the effect on the permeability of the intestine and the stimulation of antitoxin production in immune animals. J. Path. Bact. 1957, 73, 511.

32. Wrong, O., A. Metcalfe-Gibson, R. B. I. Morrison, S. T. $\mathrm{Ng}$, and A. V. Howard. In vivo dialysis of faeces as a method of stool analysis. I. Technique and results in normal subjects. Clin. Sci. 1965, 28, 357. 